\title{
Nation-Building, Revolution and the Advance of the Red Army Into Lithuania, 1918-1919
}

\section{Tomas BALKELIS}

\begin{abstract}
This article explores the initial conjunction and subsequent disentanglement of social and nationalist revolutions in Lithuania by focusing on the impact that war and various mobilizations had on the local population in 1918-19. Despite the explosion of social and nationalist unrest all over the country in late 1918, in a matter of several months the Bolsheviks lost their case. The key reasons for their failure were their military defeat by German, Lithuanian, and Polish troops, but also economic mismanagement, the refusal to distribute land to peasants, and an inability to present their revolution as "native." Following the Leninist doctrine of "proletarian revolution" that relegated peasantry to a secondary position, the Bolsheviks failed to forge an alliance with the largest population group of Lithuanian society, which resulted in their downfall.
\end{abstract}

Keywords: Bolshevism, social radicalism, revolution, land reform, peasantry, propaganda, mobilization

\section{Introduction}

Between 1914 and 1918 Lithuania was transformed from a north-western Tsarist borderland into a nation-state that proclaimed its independence on February 16, 1918. The bitter fighting between imperial German and Russian armies, the displacement of more than half a million of war refugees, exploitative German occupation, and Germany's defeat in November 1918 led to the collapse of state power, social disorder, and popular unrest in the region. The advance of the Red Army in late 1918 opened new opportunities for several new political regimes, but also plunged the region into another war. This article will examine the tumultuous junction of 1918 and 1919 by focusing on the impact that the Russian revolution and continuous warfare had on state-building in the country.

The emergence of Bolshevik rule in Lithuania in 1918-19 is still a contested subject. If Soviet authors saw it as an extension of the socialist revolution in Russia- "part of a coherent revolutionary process," as a leading Soviet Lithuanian historian noted ${ }^{1}$-nationally minded historians view it as "Bolshevik expansion"

1 Bronius Vaitkevičius, Pirmoji darbininkųir valstiečiu valdžia Lietuvoje (Vilnius: Mokslas, 1988), 7. Typical Soviet accounts of the revolution in Lithuania can be found in Povilas Vitkauskas, Lietuvos Tarybu respublikos sukūrimas 1918-1919 metais (Vilnius: Mokslas, 1978); Juozas Žiugžda, Lietuviu tautos kova dèl tarybu valdžios 1918-1919 metais (Vilnius: Valstybinèpolitinès literatūros leidykla, 1948). 
or "Russian occupation." If the first were mostly preoccupied with finding evidence for "the proletarian revolution," the second group argues there was a national revival that occurred as a result of Bolshevik intervention, national mobilization, and the struggle for independence. With different variations, both camps view "class" and "nation" as essentialist categories that stand at the core of their interpretations.

There are also those who try to bring together these two exclusionist narratives by pointing to the entanglement of social and national issues during the period. Some argued that, in 1918-19, in the non-Russian borderlands, purely nationalist demands went along with or were even eclipsed by radical social and economic policies. ${ }^{3}$ Thus, Ronald Suny claimed that "here the social and ethnic are so closely intertwined that separation of the two can be artificial and misleading." ${ }^{4}$ Stephen Jones noted "that even if we accept that nationalist parties ... played a significant role among non-Russians in 1917, the most popular of them were equally committed to a socialist land reform program." ${ }^{5}$

In Lithuania, like almost everywhere in the former Russian empire, after the October revolution workers were generally inclined to social radicalism. However, they were only a minority in an agrarian society made up largely of peasants. ${ }^{6}$ In general, the Bolshevik reliance mostly on workers severely limited their chances of successful mobilization in the borderlands. In the meantime, peasants, though more conservative than workers, lived through their own "peasant revolution." For them the issues of self-government (often understood also in lingu-

2 Most notable among those accounts are: Kazys Ališauskas, Kovos dèl Lietuvos nepriklausomybès 1918-1920, Volume 1 (Chicago: Ramovè, 1972); Vytautas Lesčius, Lietuvos kariuomene nepriklausomybes kovose 1918-1920 metais(Vilnius: Lietuvos karo akademija, 2004); Pranas Čepenas, Naujujų laiku Lietuvos istorija, Volume 2 (Vilnius: Lituanus, 1992).

3 Ronald Suny, ed., The Cambridge History of Russia, Volume 3 (Cambridge: Cambridge University Press, 2006), 131. Among other works that hold this perspective, see Geoff Eley, "Remapping the Nation: War, Revolutionary Upheaval and State Formation in Eastern Europe, 1914-1923," in Ukrainian-Jewish Relations in Historical Perspective, eds. Howard Aster and Peter Potichny (Edmonton: Canadian Institute of Ukrainian Studies, 1990); Ronald Suny, The Revenge of the Past: Nationalism, Revolution, and the Collapse of the Soviet Union (Stanford: Stanford University Press, 1993); Stephen Jones, “The Non-Russian Nationalities," in Society and the Politics in the Russian Revolution, ed. Robert Service (New York: St. Martin's Press, 1992).

4 Ronald Suny, "Nationalism and Class," in Revolution in Russia: Reassessments of 1917, eds. Edith R. Frankel, Jonathan Frankel and Baruch Knei-Paz (Cambridge: Cambridge University Press, 1992), 223.

5 Jones, "The Non-Russian Nationalities," 40.

6 Based on the data of the Russian census of 1897, in Vilnius and Kaunas there were 20,000 and 6,900 workers respectively. Vytautas Merkys, Lietuvos pramones augimas ir proletariato formavimasis XIX amžiuje (Vilnius: Mintis, 1969), 365. 
istic and cultural terms) went along with their key social demand: redistribution of land, equally shared by landless peasants and smallholders that constituted the majority of the peasantry in Lithuania. At least initially, this was more important for them than national self-determination.

Nevertheless, in Lithuania, like in Latvia or Estonia, nationalism in the longer run proved more successful because, among other reasons, it became reinforced by class divisions. ${ }^{7}$ The old hostility between Polish-speaking landlords and Lithuanian peasants was fertile ground for radical social and nationalist demands in the post-war period. However, as we will see, the Lithuanian national government adopted some ideas of social justice more successfully than the local Bolshevik regime. Both sides offered self-determination (even if the Bolshevik offer came with strings attached to Soviet Russia). However, only the nationalists were willing to redistribute the land to peasants.

Thus, in spite of the initial convergence of national and social issues brought by the February revolution, the non-Russian borderlands, including Lithuania, also saw fierce competition between nationalist and Bolshevik state-building projects. The conflict flared after the Allies and Germany decided to stop the Bolshevik advance into the region in late 1918. The eruption of war was a key moment that changed the dynamics between the two projects. Mobilization of local manpower, economic resources, and fierce agitation campaigns stiffened the boundaries between revolutionary and nationalist camps, which initially seemed flexible and permeable.

This rivalry took place not only between socialists and nationalists: it also occurred within their camps. In the ethnically mixed borderlands, nationalist mobilizations led to the polarization of populations along ethnic lines and, by extension, to inter-nation-state conflicts. Those ethnicities that had been freed from the shackles of empire now turned against each other. In Lithuania the most obvious example was the Polish-Lithuanian rivalry that, from April 1919, developed into a smouldering low-scale war between two states. On the other hand, the local socialist revolution competed with the Bolshevik attempt to import their own "proletarian revolution" by arms. Paradoxically, the Bolshevik intervention produced a backlash not only among the nationalists, but also among some local revolutionaries.

More specifically, in this article, I will explore the initial conjunction and subsequent disentanglement of social and nationalist revolutions in Lithuania in late 1918 and 1919. Despite the explosion of social and nationalist unrest all over the country in late 1918, in a matter of several months the Bolsheviks lost their case.

7 Suny, ed., The Cambridge History of Russia, 131. 
The key reasons for their failure were their military defeat by German, Lithuanian, and Polish troops, but also economic mismanagement, the refusal to distribute land to peasants, and an inability to present their revolution as "native."

\section{Social Radicalization of the Lithuanian Population}

The social radicalization of the Lithuanian population was largely a result of social disaster and state failure brought about by the Great War, German occupation, and the Russian revolution. One of the most notable features of social radicalization in Lithuania was that there a socialist revolution started before the advancement of the Red Army into the country. It was not imported on the bayonets of Red troops. Rather, it grew up from the local civilian experience of the Great War, German occupation, state collapse, and social disaster that engulfed the whole country in late 1918. Initially, the revolution had a clear antiGerman character and was fuelled by economic hardship. Very often it was led by radicalized war veterans and former refugees. It occurred both in major cities and towns, but also in the countryside where agricultural workers, landless peasants, and smallholders tried to establish their self-government. The most restive regions were Žemaitija (north-west Lithuania) and northern Aukštaitija (Šiauliai and Panevežys regions), while Suvalkija (south-west Lithuania) and central Lithuania (Kaunas region) were relatively more peaceful.

Two of the most typical revolutionary activities were the creation of local soviets or socialist committees and Red paramilitary bands that tried to take control of various localities. Interestingly, these structures started emerging simultaneously alongside parish or municipal committees and self-defence militias loyal to the Lithuanian government. The nationalist bodies started springing up after the first public appeal of the Augustinas Voldemaras cabinet to Lithuanian society on November $13,1918 .^{8}$ The competition between, on the one hand, the socialists and, on the other hand, the nationalists and clericals led to disorder. Socialists agitated within parish committees, while the latter, often led by priests and the intelligentsia, refused to acknowledge "bolshevized committees." Often centrally appointed district representatives (igaliotiniai) had to resign because local revolutionized bodies refused to acknowledge them. ${ }^{9}$ Also there were cases when locally elected soviets or revolutionary committees considered themselves

8 The parallel process is well described by Česlovas Laurinavičius, ed., Lietuvos istorija: nepriklausomybè, 1918-1940, Volume 10, Part 1 (Vilnius: Baltos lankos, 2013), 117-18.

9 See the case of Jurbarkas (western Lithuania) in Aistè Morkūnaitè-Lazauskienè, Iš vietos savivaldos istorijos Lietuvoje: 1918-1919 metų dokumentai Lietuvoje (Šiauliai: Šiaulių universiteto leidykla, 2010), 19. 
superior to any central government. ${ }^{10}$ An important feature of this local activism was that, at least initially, it was not led and controlled by the national or Bolshevik governments based in Kaunas and Vilnius.

This social activism greatly intensified after the Armistice of November 11, 1918 and the German revolution. Local Bolsheviks spearheaded the social unrest, though their presence was more considerable in cities and towns than in villages. In December 1918 and early January 1919, the Bolsheviks were able to take control of majorities in workers' soviets in Kaunas, Šiauliai, and Panevėžys. ${ }^{11}$ In its report the Central Committee of the Lithuanian-Belarusian Communist Party noted that "after the putsch in Germany our party work completely changed." ${ }^{2}$ In October-November 1918, the Communists were able to establish six new regional branches in Vilnius, Kaunas, Šiauliai, Panevėžys, Marijampolè, and Vilkaviškis, each containing regional committees of 5-7 members. The largest of them emerged in Vilnius; it had more than 250 members, while in the city of Kaunas there were about 160. In the Siauliai region they ran 45 local cells that contained about 480 members, and in the Panevezzys region they had eight groups with 180 people. "From the putsch until today [December 8,1918$]$ the ranks of our sympathizers grew up by three and four times in all regions ... The work is moving ahead . .. Tomorrow we will start a battle," the report concluded. ${ }^{13}$

The brunt of accumulated popular resentment most often spilled out against the remaining German troops. The fact that the Germans continued their requisitions even after the creation of their civilian government in mid-November 1918 only added to the anguish of the population, since now the locals considered them illegal. ${ }^{14}$ Demobilizing soldiers tried to put their hands on everything that remained accessible before any local government structures could emerge. Thus, in Antalieptè, local farmers had to organize armed patrols to protect their previously requisitioned grain from the Germans. ${ }^{15}$ On November 24 the official mouthpiece of the Taryba [Lithuanian Council], Lietuvos aidas, reported:

In some localities shops are ransacked, German patrols are attacked, transports are stopped, telegraph and railway lines are damaged. We received such news from the districts of Vilnius, Molètai, Širvintos, Rodunè and Baltstoge. ${ }^{16}$

\footnotetext{
${ }^{10}$ Morkūnaitè-Lazauskienė, Iš vietos savivaldos istorijos, 19.

${ }^{11}$ Alfonsas Eidintas and Gediminas Rudis, eds., Naujas požiūris į Lietuvos istoriją (Kaunas: Šviesa, 1989), 27.

${ }^{12}$ Juozas Žiugžda, ed., Lietuvos TSR istorijos šaltiniai(Vilnius: Valstybinè politinès ir mokslinès literatūros leidykla, 1958-1961), 3: 89.

13 Žiugžda, ed., Lietuvos TSR istorijos šaltiniai, 3: 88-90.

${ }^{14}$ German military authorities acknowledged they had problems with their marauding troops and promised to discipline them. See, Žiugžda, ed., Lietuvos TSR istorijos šaltiniai, 3: 234.

${ }^{15}$ Lietuvos aidas (3 December 1918), 2.

${ }^{16}$ Lietuvos aidas (24 November 1918), 3.
} 
In the county of Naujamiestis (west Lithuania) two former Lithuanian war refugees formed an armed Communist band and attacked the German troops that requisitioned cattle from local farmers. ${ }^{17}$ Similar attacks against the Germans followed in other regions of the country. The most successful and largest of them took place in Šiauliai when, on January 8, 1919, a locally mobilized Red band of several hundred men led by an ex-Russian army NCO, Feliksas Žemaitis, cleared the town completely of German troops. ${ }^{18}$ Two successive German attempts to retake Šiauliai with armored trains were unsuccessful.

In some localities, for example in Kuršenai, Seda, and Židikai (all in north Lithuania), revolutionized committees also attempted to take over the properties of local landlords, though similar actions were not widespread all over the country. ${ }^{19}$ There were also sporadic socially motivated attacks, burning of mills, and killings of landlords in Kupiškis and Kaišiadorys districts. ${ }^{20}$ These attacks against propertied owners and well-to-do farmers came alongside an increasing wave of banditry in the countryside that reached its highest peak in late 1918. Both the nationalist and socialist press reported almost daily cases of armed assaults and robberies. For example, a correspondence from the Akmenè district (northern Lithuania) claimed there were about thirty victims of assaults, of which four were manslaughters, in the fall of $1918 .{ }^{21}$

In December and January local soviets and paramilitary Red bands sprang up all over northern and eastern Lithuania. They emerged in Mažeikiai, Seda, Kuršènai, Panevėžys, Kupiškis, Rokiškis, Švenčionys, Joniškèlis, Šiauliai, Joniškis, Kretinga, and other areas. ${ }^{22}$ The size of their memberships ranged from small units, such as in Seda (eleven), to larger ones in Kuršènai (forty), Kupiškis (sixty), and Šiauliai (1,000). Their lifespan was usually short: from a few weeks to several months. Some of these paramilitary formations were able to act independently and at least initially maintained little or no contact with the advancing Red Army. They were able to control some territories for a considerable time and engaged in occasional military violence against the retreating Germans, landlords, and local parish committees loyal to the government in Kaunas.

${ }^{17}$ Žiugžda, ed., Lietuvos TSR istorijos šaltiniai, 3: 90.

${ }^{18}$ Vaitkevičius, Pirmoji darbininkų ir valstiečių valdžia Lietuvoje, 115.

${ }^{19}$ Ibid., 121.

${ }^{20}$ Dabartis (26 October 1918); Tiesa, no. 53 (1918). Quoted in Vincas Kapsukas, Pirmoji Lietuvos proletarinè revoliucija ir Tarybų valdžia Lietuvoje(Chicago: Vilnis, 1934), 59.

${ }^{21}$ Darbo balsas (19 November 1918), 4.

${ }^{22}$ Bronius Vaitkevičius, Socialistinè revoliucija Lietuvoje 1918-1919 metais (Vilnius: Mintis, 1967), 421,605 . 
A typical Bolshevik revolutionary committee was created in Kuršenai (near Šiauliai) in December 1918. By the end of the month it had 200 armed men led by Domas Budinas, a former refugee who had participated in both Russian revolutions. Their weapons were taken by force from retreating German units and local landlords. On January 9, 1919 they took over the headquarters of the local Lithuanian government. Some of the pro-government militias joined the Red band. ${ }^{23}$ When the International Division of the Red Army advanced into the area in January, the band joined it.

However, the Bolsheviks were only one group among various stripes of leftwing revolutionaries who tried to establish their self-government in the countryside. In north-western Lithuania, the towns of Kretinga, Plungè, Salantai, and Skuodas were controlled by local soviets and militias made up of socialist revolutionaries. ${ }^{24}$ On January 1, 1919 in Seda (north Lithuania) the local soviets of several towns joined their forces to create the Military Revolutionary Committee of Žemaitija (Žemaitijos karinis revoliucinis komitetas), led by Budinas. When on January 27, 1919 it issued a manifesto calling for the Communist takeover of the whole Žemaitija, it was publicly reproached by the Bolshevik government in Vilnius for totally ignoring the key manifesto of the Communist Party of Lithuania, which had earlier proclaimed Soviet rule in Lithuania. ${ }^{25}$ Meanwhile, the committee was pressured not only by the Vincas Kapsukas government in Vilnius (to be discussed later), but also by armed cells of socialist revolutionaries that had formed in Kretinga, Plungè, and Salantai. ${ }^{26}$ The latter saw the Bolsheviks not as their allies, but rather as competitors for the struggle for power in Lithuania.

Tensions also emerged between Feliksas Baltušis-Žemaitis, the commander of the Žemaičiu pulkas, the largest Red paramilitary formation containing about 1,000 people, and the leadership of the 2nd Latvian Division of the Red Army. After its arrival in Šiauliai in late February, the Red Army took away an armoured train that belonged to the Žemaičiu pulkas. It also tried to appropriate its best horses and a car belonging personally to Baltušis-Žemaitis. The latter refused to cooperate, which led to the involvement of Leon Trotsky himself in the dispute. Unhappy at the attitude of the Red Army, Baltušis-Žemaitis later admitted that after the arrival of the Red Latvians, his unit suddenly lost the support of the local population. His hopes that the Lithuanians could establish

\footnotetext{
${ }^{23}$ Kapsukas, Pirmoji Lietuvos proletarinè revoliucija ir Tarybu valdžia Lietuvoje, 150.

${ }^{24}$ Vaitkevičius, Pirmoji darbininkų ir valstiečių valdžia Lietuvoje, 124.

${ }^{25}$ The manifesto of the Committee is published in Žiugžda, ed., Lietuvos TSR istorijos šaltiniai,

3: 137. For its criticism see Komunistas, no. 30 (1919), 2.

${ }^{26}$ Vaitkevičius, Socialistine revoliucija Lietuvoje, 431.
} 
their own Red rule in the country were completely dashed. ${ }^{27}$ It seems that the presence of foreign Red troops significantly changed the dynamics of socialist revolution in the area.

Yet the most visible example of the split that had occurred within the ranks of left-wing radicals was the case of the Vilna Soviet of Worker Deputies that was elected by city workers on December 15, 1918. The Communists received 96 seats; yet the other 124 were divided among Bundists, and Lithuanian and Belarusian Social Democrats. ${ }^{28}$ On the same day the Vilna Soviet declared itself the only legal government in the city. It removed censorship, forbade the export of food stuffs from the city, and froze all food prices to prevent speculation. ${ }^{29}$ The next day the city witnessed a demonstration that drew about 1,000 workers of various ethnicities carrying red flags on to the central streets. ${ }^{30}$ The Vilna Soviet also called volunteers to join its own "municipal militia." ${ }^{11}$ On December 24 it organized a major strike of workers to protest against the arrests of several dozen workers by German troops. The arrests were provoked by their attempt to control the railway traffic of German echelons. The city went dark as its electric supply was switched off and all printing houses were shut off. As the tension grew, the Germans agreed to release some of the prisoners. ${ }^{32}$

On December 22 and 28, the Vilna Soviet, having learned that the Kapsukas government of the Lithuanian Socialist Republic declared itself the only government in Lithuania on December 8, protested vociferously by declaring that the latter "was appointed by Bolshevik commissars in Moscow. Therefore, it has no right to claim the government." ${ }^{3}$ The Communist Party was accused of "the dictatorship over the soviets." ${ }^{34}$ The Vilna Soviet survived a bloody attack from Polish volunteers in late December in Vilnius, but it did not survive the Bolshevik

27 „A Note of 10 November 1919 from Feliksas Baltušis-Žemaitis, the leader of the Žemaičiu pulkas, to Rapolas Rasikas, a member of the Central Committee of the Communist Party of Lithuania and Belarus, about the organization of the regiment and the unsuccessful struggle against Lithuanian and German volunteers (in Russian)," Lietuvos ypatingasis archyvas (LYA) F. 77, A. 2, B. 56, 1. 7-8.

${ }^{28}$ Komunistas, no. 1 (20 December 1918), 2.

${ }^{29}$ Darbo balsas (20 December 19180, 3; Kapsukas, Pirmoji Lietuvos proletariné revoliucija ir Tarybu valdžia,142-3.

${ }^{30}$ Laisvoji Lietuva (19 December 1918), 3. Kapsukas claims there were 20,000 demonstrators, which is hardly believable given his proclivity to Soviet propaganda. See Kapsukas, Pirmoji Lietuvos proletarinè revoliucija ir Tarybu valdžia, 138.

${ }^{31}$ Laisvoji Lietuva (21 December 1918), 3. According to one estimate, it included 60 armed workers in mid-December. See, Vaitkevičius, Pirmoji darbininkų ir valstiečių valdžia Lietuvoje, 99.

${ }^{32}$ Laisvoji Lietuva (28 December 1918), 2.

${ }^{33}$ Laisvoji Lietuva (28 December 1918), 1.

${ }^{34}$ Komunistas, no. 3 (24 December 1918), 1. 
takeover a month later. In January 1919 the Bolsheviks won the next election to the Vilna Soviet by allowing the Red Army soldiers to vote, and took it over. ${ }^{35}$

In Vilnius the Bolsheviks faced not only the opposition of the local Soviet, but also a mass organization of Polish Catholic workers. The Workers' League of St. Casimir (Liga robotnicza Sw. Kazimierza) created by a German Jesuit, Friedrich Muckermann, had about 9,000 members. ${ }^{36}$ When the league decided to publish their own newspaper for workers, the Bolsheviks tried to arrest him. The city's workers rallied to a local church and tried to prevent his departure. The Bolshevik militia staged a siege of the church that lasted for three days and ended in its violent storming on February 12, 1919. Several workers were severely beaten, while their leader was captured and imprisoned. ${ }^{37}$ The episode showed that the Bolshevik regime was not ready to tolerate any workers' organizations, except those established by them. For the Bolsheviks, keeping the monopoly on the workers' revolution was as important as fighting their White opponents.

\section{The Emergence of the Lithuanian Soviet Republic}

There is a debate about the nature of the political entity called the Lithuanian Soviet Republic (LSR), that was presumably declared on December 16, 1918 in Vilnius. Some scholars refuse to acknowledge its statehood, seeing it as a straightforward Bolshevik attempt to occupy the country. ${ }^{38}$ Pro-Soviet historians claim it as a genuine expression of the native socialist revolution. ${ }^{39}$ The third group acknowledges its formal existence, but sees it as an artificial entity created by Moscow for tactical reasons. ${ }^{40}$

Perhaps all sides of the debate have to concede that, at least formally, the LSR had its own government, claimed a defined territory, and was able to control parts of it for a considerable period of time. Nevertheless, the idea of its creation was born in the Bolshevik circle of Lenin and Stalin in Moscow, not in the minds

35 Čepènas, Naujujų laikų Lietuvos istorija, 2: 327.

${ }^{36}$ Jurgis Matulaitis, Užrašai (Putnam (Conn): Nekaltai Pradètosios Mergelès Marijos Seserys, 1991), 187.

${ }^{37}$ GenovaitėGustaitè, “Kaip vyskupas Jurgis Matulaitis gelbejo T. Frydrichą Mukermaną,” Lietuvos Kataliku Mokslo Akademijos metraštis, vol. 21 (Vilnius, 2002), 608.

${ }^{38}$ Čepenas, Naujujų laiku Lietuvos istorija, 2: 320-5. See also the works of Lesčius and Gediminas Surgailis.

${ }^{39}$ Vitkauskas, Lietuvos Tarybu Respublikos sukūrimas 1918-1919 metais, 217; R. Šarmaitis, Darbo žmonių kova dèl Tarybų valdžios Lietuvoje 1918-1919 metais (Vilnius: Valstybinèpolitinèliteratūros leidykla, 1948), 17; KęstutisDomaševičius, Tarybinio valstybingumo vystymasis Lietuvoje (Vilnius: Mintis, 1966), 7-19.

${ }^{40}$ Alfred Senn, The Emergence of Modern Lithuania(New York: Columbia University Press, 1959); Laurinavičius, ed., Lietuvos istorija, Vol. 10, Part I. 
of Lithuanian Bolsheviks. The LSR also never had its own troops, an attribute critical to any state sovereignty. It was the Red Army that brought the LSR to Lithuania and ensured its survival. This is not to say that the Bolsheviks did not spare much effort trying to make the entire state-building project look native. There is little doubt that the LSR was a tactical move by Soviet Russia to legitimize the establishment of Bolshevik rule in newly acquired Lithuania. Yet the Bolshevik takeover should be seen in a broader context of the nationality policies of the Bolshevik government and its attempts to establish similar republics in other peripheries of the former Russian empire.

The Soviet policy toward Lithuania and other non-Russian western borderlands of the former Russian empire was born as a result of the sudden shift in the Bolshevik policy of nationalities that occurred in January 1918, when Lenin, contrary to his earlier anti-federalist views, pushed to establish "the Soviet Russian Republic ... on the basis of a free union of free nations, as a federation of Soviet national republics." ${ }^{41}$ Under his initiative, this principle became inscribed in the Constitution of Soviet Russia adopted on July 10, 1918. This federalist policy was a practical response of the Bolsheviks, who found themselves in a deep crisis when non-Russian borderlands started splintering from Russia one after another after the Bolshevik coup..$^{42}$ Thus, on November 20, 1917, the Ukrainians were the first to establish the Ukrainian People's Republic (initially, within a federal democratic Russia). ${ }^{43}$ On December 6, Finland declared its independence; Georgia, Armenia, and Azerbaijan followed suit. On December 11, 1917 (and then again on February 16, 1918), the Lithuanian Taryba issued its own independence manifesto. Latvia did the same on January 15, 1918, and Estonia followed on February 24, 1918. The Bolsheviks hoped that the introduction of the principle of ethnographically defined Soviet national republics would help them to reunite Russia's lands and peoples. ${ }^{44}$

The first precedent of the new Bolshevik "borderland policy" was set in Ukraine, when, in response to the Rada's decision of November 20, the Bolsheviks "outlawed" the Rada by declaring their own Socialist Republic of Ukraine in Kharkiv on December 25, 1917. Moreover, the new Bolshevik "government" of Ukraine pledged its allegiance to Soviet Russia and recognized its laws to be

${ }^{41}$ Lenin is quoted in Richard Pipes, The Formation of the Soviet Union: Communism and Nationalism, 1917-1923 (Cambridge: Harvard University Press, 1964), 111.

${ }^{42}$ Jeremy Smith, Red Nations: the Nationalities Experience in and after the USSR (Cambridge: Cambridge University Press, 2013), 22.

${ }^{43}$ Serhy Yekelchyk, Ukraine: Birth of a Modern Nation (Oxford: Oxford University Press, 2007), 114.

${ }^{44}$ Francine Hirsch, Empire of Nations: Ethnographic Knowledge and the Making of the Soviet Union (Ithaca: Cornell University Press, 2005), 67. 
applicable to Ukraine. ${ }^{45}$ In early January 1918 the Kharkiv Bolsheviks sent a Red Guard, the majority made up of troops sent from Russia, to crush the Ukrainian national government. By defeating it, the Bolsheviks learned that this model of revolutionary takeover was highly successful. It helped to legitimize their rule by merging their class aspirations with those of the locals and the principle of national self-determination.

Most importantly, this principle, which was one of their major slogans in the October revolution, now became increasingly interpreted as the right to secession that could be exercised only by the local proletariat. This was a creative, yet highly dogmatic, ideological invention of the Bolsheviks to justify their conquests, since very few non-Russian peripheries had significant numbers of workers. ${ }^{46}$

The "Ukrainian pattern" was soon followed in other non-Russian areas contested between the Bolsheviks and various national governments. The independence declarations of Finland (December 6, 1917), Latvia (January 15, 1918), and Estonia (February 24, 1918) were quickly challenged by Soviet Russia by the creation of socialist "state entities" in Finland (January 29, 1918), Estonia (February 24, 1918), and Latvia (December 17, 1918). Remarkably, all of them were declared in peripheral towns because the Bolsheviks did not control these territories or held only some of them. In the Baltic states, like in Ukraine, they were also supported by the direct military intervention of the Red Army, now interpreted as Russian workers' help to local proletarians.

The proclamation of the Lithuanian Soviet Republic happened in highly confusing circumstances during late 1918. Kapsukas arrived in German-occupied Vilnius on December 2, 1918. On December 9 he and his few fellow Communists produced an initial version of their declaration. However, the final version, dated December 16 and signed in Vileika (west Belarus), was first published, not in Lithuania, but in Moscow on December 19. ${ }^{47}$ In Vilnius it came out only on December 24, two days after Soviet Russia officially recognized the LSR. ${ }^{48}$ The main reason for this delay was that first, the declaration had to be approved by the Communist leadership in Moscow. On December 10 Kapsukas left Vilnius for Daugavpils (Dvinsk), where he presumably waited for its approval..$^{49}$ It turned out that Stalin made a considerable revision to the initial version by striking

45 Pipes, The Formation, 123.

${ }^{46}$ Richard Pipes credits Stalin with this interpretation of "proletarian self-determination" which he proposed to Lenin in connection with the Ukrainian crisis. Initially, Lenin did not accept it because he believed that only in Russia the proletariat was ready for sovereignty, but he was forced to endorse it by the further course of events. See, Pipes, The Formation, 109.

${ }^{47}$ Vitkauskas, Lietuvos Tarybų respublikos sukūrimas1918-1919 metais, 97.

${ }^{48}$ Komunistas, no. 3 (24 December 1918), 1.

${ }^{49}$ Laurinavičius, ed., Lietuvos istorija, Vol. 10, Part I, 121. 
out "Long live the RSFSR with Soviet Lithuania that has joined it!" and replacing it with "Long live the free Lithuanian Socialist Republic!" ${ }^{50}$ In his memoirs, Kapsukas later wrote:

At that time, we, Lithuanian Communists, did not have a clear answer to this issue [of independence] as we do now. ... In regard to Lithuania, Stalin proposed to create a revolutionary Lithuanian government as early as December. At the time this proposal seemed to us too hasty, because, in the opinion of the Lithuanian and Belarusian Communist Party, the revolutionary struggle was not developed enough. Secondly, for many years we fought against social-patriotism, separatism and Lithuanian independence ... therefore, we could not resolutely accept the creation of the independent revolutionary government in Lithuania. ${ }^{51}$

Thus local Bolsheviks, including Kapsukas, who for many years adhered to the radical views of Rosa Luxemburg on the nationality issue, were quite lost by the sudden shift of this policy in Moscow. The insistence of the Bolshevik leadership to create ethnically based "socialist republics" seemed to them premature and incomprehensible.

The Soviet government cautiously recognized that the invasion of the Red Army into the Baltic states may produce hostility among local populations. On November 29, 1918 Lenin telegraphed to the Commander of the Western Front, Jukums Vācietis, that the creation of the Soviet republics "has a positive side, because it takes away from the chauvinists of Ukraine, Lithuania, Latvia and Estonia an opportunity to view the movement of our troops as occupation and creates a positive mood for their further movement." 52

Indeed, in late December, upon their arrival to Lithuania, the Red Army was initially welcomed by the local population. In his December 22, 1918 telegram to Stalin, Kapsukas noted: "in Lithuania poor local people from villages welcome us as their own . . . Many volunteers keep arriving." ${ }^{53}$ Upon its arrival to Vilnius on January 6, 1919, the Red Army was greeted on the streets by the city's workers with red flags. On January 15, Lenin was informed again that the Red Army in Vilnius "was met with joy," "it behaves in an exemplary fashion," and "mobilization of volunteers is successful," despite "the starvation in the city" and "huge

${ }^{50}$ A. Deruga, "Przyczynek do genezy Litewskiej Republiki Radzieckiej i dziejów wojny domowej na przełomie lat 1918-1919," in Z dziejów stosunków polsko-radzieckich, vol. 9, (Warszawa: Książka i Wiedza, 1972), 213-19.

${ }^{51}$ Kapsukas, Pirmoji Lietuvos proletarinè revoliucija ir Tarybų valdžia Lietuvoje, 119-20.

${ }^{52}$ Directives of the Supreme Command of the Red Army, 1917-1920 (Moscow, 1969), 179.

${ }^{53}$ A telegram of Kapsukas and Pestkovski to Stalin, 22 December 1918, GARF (State Archive of Russian Federation) F. 130, O. 2, D. 819, s. 18-19. 
speculation in currencies." 54 The local press also noted that after the arrival of the Bolsheviks the price of bread skyrocketed and most of the shops became empty of foodstuffs. ${ }^{55}$

Having arrived to the city on January 7, Kapsukas proceeded to organize the whereabouts of his government. Yet the LSR immediately faced a shortage of specialists able to fill new government positions. Lenin was soon telegraphed to be informed that the new government took the decision to "invite the representatives of the local intelligentsia." ${ }^{6}$ Its further actions, however, produced bewilderment among the city's population as, in a matter of a few days, the Red Army started to transport raw materials and foodstuffs to Soviet Russia. On December 26, 1918 the LSR government legalized requisitions and ransoms (kontribucijos) taken from "all rich people." ${ }^{57}$ Yet on January 23, 1919 Kapsukas protested to Lenin urging him "to stop the transportation of all types of material goods, because Vilnius is totally ravaged by the German occupation.... and this policy may damage the image of the Soviet rule in the country and also may hinder the formation of our new military units." ${ }^{58} \mathrm{He}$ banned the export of foodstuffs from the city and the arrival of starving civilians from central Russia. Nevertheless, this early episode already showed the challenges that the new regime would face in the near future.

Contrary to the Bolshevik behaviour in Estonia, Latvia, Russia, and Ukraine, in Lithuania the local Soviet regime did not resort to mass terror and the physical liquidation of its ideological enemies. There were almost no attacks against churches; while anti-Bolshevik newspapers continued to be published in Vilnius until mid-February 1919..$^{59}$ The relatively benevolent nature of the Kapsukas government was also most visible in the collaboration between the regime and the local nationally minded intelligentsia. It seems that those Lithuanian activists who remained in Vilnius were more relieved that the Poles lost the city than aggrieved about the Bolshevik takeover. An article in the Christian Democratic newspaper, Laisvoji Lietuva, stated:

If Lithuanians will stay at the forefront of running the country ... then we can look at the new occupation of Lithuania calmly ... It doesn't matter whether we are going to call the new government a dictatorship of the proletariat or a Soviet government. ${ }^{60}$

\footnotetext{
${ }^{54}$ A telegram of A. Mazhnicki to Lenin, 15 January 1919, GARF F. 130, O. 3, D. 6006, s. 7.

${ }^{55}$ Laisvoji Lietuva, no. 2 (8 January 1919), 2.

${ }^{56}$ A telegram of A. Mazhnicki to Lenin, 15 January 1919, GARF F. 130, O. 3, D. 6006, s. 7.

${ }^{57}$ Lietuvos Laikinosios revoliucinès vyriausybès instrukcija apie Lietuvos revoliucinius komitetus, Lietuvos TSR istorijos šaltiniai, 3: 116.

${ }^{58}$ A telegram of Kapsukas to Lenin, 23 January 1919, GARF F. 130, O. 3, D. 6006, s. 8.

59 Laurinavičius, ed., Lietuvos istorija, Vol. 10, Part. 1, 127.

${ }^{60}$ Laisvoji Lietuva, no. 2 (8 January 1919), 1.
} 
A Lithuanian delegation led by Juozas Tumas that visited Kapsukas on January 9, 1919 was prudently impressed by the new regime, and especially by his promises to allow Lithuanians to continue their cultural activities in the city and by the government's decision that Vilnius will be the capital of the LSR ${ }^{61}$

As it turned out, many of those Lithuanian writers, academics, and artists who decided not to evacuate with the Lithuanian government to Kaunas in late December 1918, were successfully employed by the Kapsukas regime as various Soviet officials and specialists. According to Česlovas Laurinavičius, at least 50 leading Lithuanian political, economic, academic, and artistic figures worked for the Kapsukas government to various degrees, including prominent leaders of the national movement such as Jonas Basanavičius, Juozas Tumas, and Jonas Jablonskis. ${ }^{62}$ It seems this collaboration was due by personal factors-after all, Kapsukas himself had been an ardent nationalist in the past and kept close contacts with his former political allies. Yet, as Laurinavičius astutely notes, their behavior also reflected "a split within the civil society." ${ }^{3}$ This did not mean that the intelligentsia suddenly became Bolshevized, rather they were attracted to the new government by its promises of social reform, support for the cultural concerns of the Lithuanian elite, and its generous funding of local educational and cultural institutions. At the same time, their behaviour also betrayed their low hopes that the Kaunas government may survive the chaotic course of events in early 1919.

On March 22, 1919 the Kapsukas government issued a decree on the equal rights of all national groups within the Soviet republic. ${ }^{64}$ It declared five languages (Russian, Lithuanian, Polish, Yiddish, and Belarusian) as official. In schools, children were allowed to receive instruction in their native language, though it was stated that "beside the native tongue, they have to learn one of the five languages that would be indicated by the Commissariat of Education." ${ }^{65}$ Yet, in practice, the Soviet language policy produced an excessive bureaucracy (in theory, most state documents had to be published in all languages) which, in turn, led to the dominance of the Russian language. Finding an easy linguistic solution in a region with a highly ethnicized population turned out to be an impossible challenge.

${ }^{61}$ Laisvoji Lietuva, no. 4 (14 January 1919), 1.

${ }^{62}$ ČeslovasLaurinavičius, "On Political Terror during the Soviet Expansion into Lithuania, 19181919,” Journal of Baltic Studies 1:46 (2015), 75.

${ }^{63}$ Ibid., 69.

${ }^{64}$ BroniusVaitkevičius, ed., Lietuvos tarybų valdžios dekretai: dokumentų rinkinys (Vilnius: Mintis, 1977), 119.

${ }^{65}$ Ibid., 122. 


\section{Bolshevik Land Reform and the Food Crisis}

The arrival of the Red Army and the creation of the LSR greatly raised the expectations of peasants for land reform. Local reports to the Kapsukas government were full of their requests to distribute land that belonged to landed estates. "Peasants are waiting for the distribution of estate lands day after day.... and we are not sure whether there will be left any undivided estates in the Ukmerge district," local Bolsheviks wrote to Vilnius. ${ }^{66}$ In fact, in some cases, as it happened in the region of Švenčionys, farmers started robbing the estates. "Local people . . started distributing estate properties, wood, windows and building materials. There are many robberies," reported a revolutionary committee from the Švenčionys district on January 22, 1919. ${ }^{67}$ The Bolshevik leadership quickly responded to the estate robberies by issuing an order "to shoot the robbers on the spot." 68

It is likely that some of these actions were precipitated by the long-awaited Bolshevik land decree of January 14, 1919. ${ }^{69}$ The decree nationalized all landed properties and their assets, confiscated all landed estates in the country, but also banned any "land sales, purchases and rents." It made an exception for smallholders by declaring that their land remained in their possession. In reality, the decree amounted to the total freezing of all kinds of land transactions in the country. It turned out that the Kapsukas regime had no desire to distribute the nationalized land to the peasants. Instead, its major effort was spent in transforming the confiscated landed properties into peoples' farms (liaudies $\bar{u}$ kiai), large-scale agricultural entities where peasants would continue working the estate land now organized into communes (komunos). ${ }^{70}$ With this policy the Lithuanian Bolsheviks consistently followed the beliefs of Lenin, who had claimed that large-scale collective farms were more efficient than small peasant plots. According to Soviet sources, there were about 3,000 peoples' farms created in Lithuania and Belarus in 1919, though it seems that most of them existed only on paper. Lithuanian Bolshevik officials openly admitted they were able to create only a few communes; peasants simply showed little interest in joining them. ${ }^{71}$ The government's efforts to revitalize its land reform by subsidizing the communes and creating tighter bureaucratic controls on food provisioning did not improve the situation.

\footnotetext{
${ }^{66}$ Vaitkevičius, Pirmoji darbininkų ir valstiečiuvaldžia Lietuvoje, 220.

${ }^{67}$ Lietuvos TSR istorijos šaltiniai, 3: 135.

${ }^{68}$ Lietuvos TSR istorijos šaltiniai, 3: 127.

${ }^{69}$ Lietuvos TSR istorijos šaltiniai, 3: 131.

${ }^{70}$ Vaitkevičius, Pirmoji darbininkų ir valstiečiu valdžia Lietuvoje, 218-19.

${ }^{71}$ S. Bobinski, "Nacjonalizacja (uspołecznienie) ziemi," in Kalendarz komunistyczny (Moscow, Smolensk, 1920), 109.
} 
In late January the Bolshevik mouthpiece Komunistas stated: "There is a danger of starvation in Lithuania. The four-year war destroyed the whole country... Vilnius has foodstuffs only for a short time ... It is no better in the countryside." 72 By February the LSR faced a major food crisis on its territory. The confiscated land estates, already depleted by German requisitions, were unable to provide enough foodstuffs to feed the population. In many cases peasants simply refused to sell their grain to Red officials because they did not want to accept the Russian currency (kerenki), which rapidly lost its value. On February 20, 1919, in Vilnius, the first Congress of the Delegates of Workers, Peasants and Soldiers sounded an alarm: "there is hunger in the country and no appropriate mechanism for food provisioning." 73

In his diary, a Catholic priest, Antanas Pauliukas, who lived in a small town near Anykščiai (east Lithuania) wrote on February 22:

Bolsheviks promised to parcel the estates, to give land, but now they keep silence about it. All goods became expensive. Hunger is inevitable, and the people think they are responsible for it. That is why people are cursing them and sending them to hell. The Bolsheviks disrupted farming with their robberies and, especially, contributions. Better-off farmers sold their horses, reduced their cattle to prevent it falling into their hands. Farmers are refusing to hire helpers to avoid misunderstandings. ${ }^{74}$

To the shock of the Kapsukas government, in mid-March 1919, local railway and electric station workers in Vilnius, exasperated by food shortages and nonregular pay, threatened the Bolsheviks with a strike. ${ }^{75}$ To deal with the crisis, Kapsukas had to import food from Ukraine. ${ }^{76}$ The regime was also forced to proceed with tougher requisitions in Lithuania. Thus, on January 13, 1919 in Panevėžys a local commissar issued an order to all local peasants to deliver their surplus grain to the authorities, threatening them with "strict measures" because "there is starvation among town people." ${ }^{77}$ Now the requisitions targeted not only well-to-do farmers, but also smallholders. Meanwhile, poorly provisioned Red troops started feeding themselves off the countryside. On February 26 the government was forced to issue a separate order to stop requisitions from the poor peasantry for fear it would lose its already dwindling support in the country. ${ }^{78}$ Nevertheless, by early May 1919 the Bolsheviks already had three "requisition squads" roaming

\footnotetext{
${ }^{72}$ Komunistas, no. 18 (31 January 1919), 2.

${ }^{73}$ Vaitkevičius, ed., Lietuvos tarybų valdžios dekretai, 80.

${ }^{74}$ Antanas Pauliukas, Dienynas, unpublished manuscript, 60.

${ }^{75}$ Vaitkevičius, Pirmoji darbininkų ir valstiečiu valdžia Lietuvoje, 230.

${ }^{76}$ Zvezda (2 April 1919), 2; Komunistas (11 April 1919), 2.

${ }^{77}$ Lietuvos TSR istorijos šaltiniai, 3: 129.

${ }^{78}$ Lietuvos TSR istorijos šaltiniai, 3: 172.
} 
the villages; their task was to supply foodstuffs to their front line units in Lithuania. ${ }^{79}$ By this time, it was quite clear that the Bolshevik agrarian policy was a total failure.

\section{The Propaganda War: Natives vs. Non-natives}

For the Šleževičius government, now based in Kaunas under the protection of German volunteers, the food crisis in the Bolshevik-controlled eastern Lithuania presented itself as a potent tool in its anti-Bolshevik agitation campaign. The campaign started almost immediately after its evacuation from Vilnius and strengthened with the first military clashes between the German-Lithuanian and Bolshevik troops in the winter of 1919. It was launched with a new force after the emergence of the government's daily Lietuva on January 11, 1919 in Kaunas. The newspaper's very first issue named two major enemies of independent Lithuania: "Polish landlords" and "Russian Bolsheviks." If the first were accused of their intention to take Vilnius, the second were plainly named "invaders of Lithuania." Oddly enough, the list of foes also included "German and Jewish speculators, merchants." All of these groups were labeled as "foreign." Thus, the Lithuanian government effectively merged the social tensions within the country with the ethnic ones: the struggle for independence against "foreigners" also implied the struggle for social reform. The "foreignness" of the Bolshevik regime was demonstrated by its attempts to take away foodstuffs from the country, their invasion creating product shortages, requisitions, general economic collapse, and disorder. Moreover, the Lithuanian government made sure that its public appeal targeted "the Lithuanian working man," as well as "our landless peasants, smallholders, and estate laborers." ${ }^{80}$ All of them were promised the land taken from Polish landlords. This appeal set the early tone for a pro-government agitation campaign that would continue with a growing vigor throughout the war.

The liberating nature of the war was reinforced by making the connection between the presence of the Soviet Russian Red Army in Lithuania and all local Bolsheviks: "When there is a bloody struggle between Lithuanian and Bolshevik armies, a virtual war between the Lithuanian state and the Soviet Russian Republic, all Bolsheviks ... must be seen as enemy agents." ${ }^{\prime 1}$ The Kapsukas government responded with its own propaganda campaign, trying to discredit the government in Kaunas as "reactionary," "bourgeois," "White," "exploitative," and as "a German puppet." By ascribing to it "the imperialist support of reactionary Western powers," it attempted to present the war as a class conflict between the

\footnotetext{
${ }^{79}$ Lietuvos TSR istorijos šaltiniai, 3: 258.

80 “Protestuokime!"Lietuva, no. 1 (11 January 1919), 1.

${ }^{81}$ Lietuva, no. 19 (1 February 1919), 1.
} 
Whites and the Reds. ${ }^{82}$ In the Bolshevik propaganda, the Lithuanian government was nothing less than a "counter-revolutionary gang" and represented "the rule of farmers and priests." ${ }^{83}$ Yet, the Bolsheviks' focus primarily on the social aspect of the conflict made them vulnerable to its national dimension. The fact that the majority of the Red Army soldiers who fought in Lithuania were Russians did not add credibility to the Bolshevik regime in the eyes of Lithuanian peasants.

Yet, the fortunes of war now depended not as much on the propaganda campaigns as on the ability of the warring camps to outperform each other on the battlefield by mobilizing all available human and economic resources. The sweeping Bolshevik takeover of Vilnius in early January 1919 swelled their appetite for the ultimate destruction of the Lithuanian government and raised their expectations for establishing military control of the whole Baltic littoral. On January 3 the Red Latvian Riflemen units occupied Riga. As the ideological lines stiffened, a military front line split Lithuania into two halves. On January 9, 1919, one of the leaders of the Lithuanian Bolsheviks, Zigmas Angarietis, confidently wrote: "Vilnius is already in the hands of the revolutionary workers. Soon we will be in Kaunas." ${ }^{4}$

\section{Conclusion}

In 1934, in the Soviet Union, Kapsukas tried to come to terms with the failure of the Bolshevik regime in Lithuania. Besides its military defeat, among the key reasons he mentioned was the inability of the Bolsheviks to carry on the land reform. Another reason was that the leadership of the LSR paid little attention to the national question, especially to the use of Russian as its working language. This helped the Lithuanian government to win the battle of propaganda by mobilizing the local population against the "foreign" Bolshevik regime. ${ }^{85}$

He also admitted that "initially, the Communist Party of Lithuania and Belarus lagged behind the rising revolutionary movement." ${ }^{86}$ Contrary to their claims, the Bolsheviks did not fully control the local revolution. Their conflicts with socialist and Catholic workers in Vilnius and the social revolutionary committees in the countryside, and their inability to control semi-independent Red paramilitary bands at the peripheries of Lithuania, speak to the multi-dimensional character of the local revolution, but also to the imported nature of the Bolshevik one.

\footnotetext{
${ }^{82}$ Komunistas, no. 8 ( 8 January 1919), 1.

${ }^{83}$ Komunistas, no. 8 (8 January 1919), 2; no. 18 (31 January 1919), 3.

${ }^{84}$ Komunistas, no. 9 (10 January 1919), 1.

${ }^{85}$ Kapsukas, Pirmoji Lietuvos proletariné revoliucija ir Tarybų valdžia Lietuvoje, 126-217.

${ }^{86}$ Kapsukas, Pirmoji Lietuvos proletarinè revoliucija ir Tarybų valdžia Lietuvoje, 217.
} 
The key challenge for the Bolsheviks was that, upon their arrival with the Red Army, they already faced local revolutions of workers, peasants, and nationally minded elites. For their purposes, the Bolsheviks were able to exploit only the first one successfully. Their inability to conquer the hearts and souls of the Lithuanian peasants was perhaps the main reason for their failure. The social reforms they had promised were delivered only to a limited extent, while they could not ensure economic stability in the territories controlled by the Red Army. Most importantly, they failed to address the most urgent social issue effectively: land reform. In the meantime, their handling of the nationality question was, to say the least, ignorant. Following the Leninist doctrine of "proletarian revolution," that relegated the peasantry to a secondary position, the Bolsheviks failed to forge an alliance with the largest population group in Lithuanian society. In this competition for the hearts and souls of the peasants, the Lithuanian national government was considerably more successful, not only in delivering a radical land reform, ensuring more economic stability in the country, and conducting military mobilizations, but also in winning the battle of political propaganda among the majority of the population by turning the Bolshevik regime into a "foreign" other.

\section{List of sources:}

Ališauskas, Kazys, Kovos del Lietuvos nepriklausomybess, 1918-1920, Volume 1 (Chicago: Ramove, 1972)

Bobinski, S.,"Nacjonalizacja (uspołecznienie) ziemi," in Kalendarz komunistyczny (Moscow, Smolensk, 1920)

Čepenas, Pranas, Naujuju laiku Lietuvos istorija, 2 vols., (Vilnius: Lituanus, 1992)

Dabartis

Darbo balsas

Deruga, A., "Przyczynek do genezy Litewskiej Republiki Radzieckiej i dziejów wojny domowej na przełomie lat 1918-1919," in Z dziejów stosunków polsko-radzieckich, vol. 9 (Warszawa: Książka i Wiedza, 1972)

Directives of the Supreme Command of the Red Army, 1917-1920 (Moscow, 1969)

Domaševičius, Kęstutis, Tarybinio valstybingumo vystymasis Lietuvoje (Vilnius: Mintis, 1966)

Eidintas, Alfonsas and Gediminas Rudis, eds., Naujas požiūris ị Lietuvos istorija (Kaunas: Šviesa, 1989)

Eley, Geoff, "Remapping the Nation: War, Revolutionary Upheaval and State Formation in Eastern Europe, 1914-1923," in Ukrainian-Jewish Relations in Historical Perspective, eds. Howard Aster and Peter Potichny (Edmonton: Canadian Institute of Ukrainian Studies, 1990) 
Hirsch, Francine, Empire of Nations, Empire of Nations: Ethnographic Knowledge and the Making of the Soviet Union (Ithaca: Cornell University Press, 2005)

Yekelchyk, Serhy, Ukraine: Birth of a Modern Nation (Oxford: Oxford University Press, 2007)

Jones, Stephen, “The Non-Russian Nationalities," in Society and the Politics in the Russian Revolution, ed. Robert Service (New York: St. Martin's Press, 1992)

Kapsukas, Vincas, Pirmoji Lietuvos proletarinè revoliucija ir Tarybų valdžia Lietuvoje (Vilnius: Valstybinè politinès ir mokslinès literatūros leidykla, 1958)

Komunistas

Laisvoji Lietuva

Laurinavičius, Česlovas, "On Political Terror during the Soviet Expansion into Lithuania, 1918-1919,” Journal of Baltic Studies 1:46 (2015)

Laurinavičius, Česlovas, ed., Lietuvos istorija: nepriklausomybe, 1918-1940, Volume 10, Part 1 (Vilnius: Baltos lankos, 2013)

Lesčius, Vytautas, Lietuvos kariuomenè nepriklausomybès kovose, 1918-1920 (Vilnius: Lietuvos karo akademija, 2004)

\section{Lietuva}

Lietuvos Aidas

Lietuvos ypatingasis archyvas (LYA) F. 77, A. 2, B. 56, 1. 7-8

Matulaitis, Jurgis, Užrašai (Putnam (Conn): Nekaltai Pradètosios Mergelès Marijos Seserys, 1991)

Merkys, Vytautas, Lietuvos pramones augimas ir proletariato formavimasis XIX amžiuje (Vilnius: Mintis, 1969)

Morkūnaitè-Lazauskienè, Aistè, Ǐ̌ vietos savivaldos istorijos Lietuvoje: 19181919 metų dokumentai Lietuvoje (Šiauliai: Šiaulių universiteto leidykla, 2010)

Pauliukas, Antanas, Dienynas, unpublished manuscript

Pipes, Richard, The Formation of the Soviet Union: Communism and Nationalism, 1917-1923 (Cambridge: Harvard University Press, 1964)

Senn, Alfred, The Emergence of Modern Lithuania (New York: Columbia University Press, 1959)

Smith, Jeremy, Red Nations: the Nationalities Experience in and after the USSR (Cambridge: Cambridge University Press, 2013)

State Archive of Russian Federation (GARF) F. 130, O. 2, D. 819, s. 18-19

Suny, Ronald, "Nationalism and Class," in Revolution in Russia: Reassessments of 1917, eds. Edith R. Frankel, Jonathan Frankel and Baruch KneiPaz (Cambridge: Cambridge University Press, 1992)

Suny, Ronald, ed., The Cambridge History of Russia, Volume 3: The 20th Century (Cambridge: Cambridge University Press, 2006)

Suny, Ronald, Revenge of the Past: Nationalism, Revolution and the Collapse of the Soviet Union (Stanford: Stanford University Press, 1993) 
Šarmaitis, R., Darbo žmonių kova dèl Tarybų valdžios Lietuvoje 1918-1919 metais (Vilnius: Valstybinè politinè literatūros leidykla, 1948)

Vaitkevičius, Bronius, Pirmoji darbininkų ir valstiečių valdžia Lietuvoje (Vilnius: Mokslas, 1988)

Vaitkevičius, Bronius, Socialistine revoliucija Lietuvoje 1918-1919 metais (Vilnius: Mintis, 1967)

Vitkauskas, Povilas, Lietuvos Tarybų respublikos sukūrimas 1918 - 1919 metais (Vilnius: Mokslas, 1978)

Zvezda

Žiugžda, Juozas, ed., Lietuvos TSR istorijos šaltiniai, Volumes 3 and 4 (Vilnius: Valstybinè politinès ir mokslinès literatūros leidykla, 1958-1961)

Žiugžda, Juozas, Lietuviu tautos kova dèl tarybu valdžios 1918-1919 metais (Vilnius: Valstybinè politinès literatūros leidykla, 1948)

\section{Rezumat}

Acest articol explorează interacțiunea inițială și disjuncția ulterioară dintre revoluțiile sociale și naționaliste din Lituania, concentrându-se asupra impactului pe care războiul și diversele mobilizări l-au avut asupra populației locale, în perioada anilor 1918-1919. În pofida izbucnirii tulburărilor sociale și naționale pe întregul teritoriu al țării, la sfârșitul anului 1918, într-o perioadă de câteva luni, bolșevicii au pierdut lupta pentru putere. Motivele esențiale pentru eșecul lor au fost înfrângerea lor militară de către trupele germane, lituaniene și poloneze, dar și gestionarea defectuoasă a economiei, refuzul de a distribui pământ țăranilor și incapacitatea lor de a-și prezenta revoluția ca fiind un fenomen autohton. Urmând doctrina leninistă a "revoluției proletare", care îi rezerva țărănimii o poziție secundară, bolșevicii nu au reușit să creeze o alianță cu cel mai mare grup de populație din cadrul societății lituaniene - țărănimea, ceea ce a dus la căderea lor finală.

Cuvinte-cheie: Bolșevism, radicalism social, revoluție, reformă agrară, țărănime, propagandă, mobilizare 